ORIGINAL ARTICLE

\title{
A Postmortem Histological Study on Percentage Volume of Parenchyma and Stroma of the Human Parathyroid Glands
}

\author{
*S Mahbub ${ }^{1}$, ASM Nurunnabi ${ }^{2}$, S Ara $^{2}$, Abdul Alim ${ }^{3}$ \\ 1Dr. Sabiha Mahbub, Department of Anatomy, City Medical College, Gazipur \\ ${ }^{2}$ Dr. Abu Sadat Mohammad Nurunnabi \& Dr. Shamim Ara \\ Department of Anatomy, Dhaka Medical College, Dhaka \\ ${ }^{3}$ Dr. Abdul Alim, Department of Anatomy, Mymensingh Medical College, Mymensingh \\ *Corresponding author
}

\begin{abstract}
A cross-sectional descriptive study was performed in the Department of Anatomy, Dhaka Medical College, Dhaka, from January to December 2008, on post mortem parathyroid glands of 60 Bangladeshi people in different age groups. A total of 207 parathyroid glands were identified in relation to posterior border of thyroid lobes and collected from those 60 cadavers. The samples were collected from the unclaimed dead bodies within 24 hours after death that were under examination in the Department of Forensic Medicine of Dhaka Medical College, Dhaka. The samples were divided into three different age groups ranging from 15 to 75 years. The three groups are group A (10-30 years), group B (31-60 years) and group C (61-90 years). From each group, 20 best prepared slides were taken for examination. The percentage volume of parenchyma (glandular portion) and stroma (fibrous part with blood vessels and fat) were estimated by the point counting technique with Zeiss-I integrating eyepiece under the light microscope at low magnification. The mean SD percentage volume of parenchyma varies 64.88 2.75 to 65.902 .33 in group A, 56.4012 .57 to 59.103 .87 in group B and 38.802 .77 to 41.50 2.38 in group C. In contrast, the mean SD percentage volume of stroma varies 33.502 .27 to 34.882 .95 in group A, 40.303 .83 to 41.564 .16 in group B and 58.502 .38 to 61.202 .77 in group C. The percentage volume of connective tissue stroma was found to increase with increasing age with simultaneous decrease in glandular parenchyma.
\end{abstract}

Key words: Parathyroid gland, histology, parenchyma, stroma

\section{Introduction}

The parathyroid glands are small endocrine glands, usually lying between the posterior lobar borders of the thyroid glands and its capsule ${ }^{1 .}$ The parenchyma of the parathyroid glands consists of three types of cells; the chief cell, the oxyphil cell and water-clear cell, which are embedded in fibrous stroma containing blood vessels with varying amounts of fat cells, depending on the patient's age and amount of body fat ${ }^{2,3}$. Throughout the late nineteenth century there was considerable confusion about the function of the parathyroid as compared to that of the thyroid ${ }^{2}$. Most experimental extirpations of the thyroid caused tetany and death, as because the parathyriods were

AKMMC J 2014; 5(1): 10-13 damaged or removed simultaneously 4,5 . MacCallum and Voegtlin had solved this confusion by showing that extirpation of the parathyroids alone led to tetany, and administration of calcium prevented tetany in parathyroidectomized animals ${ }^{5}$. Thus ended a long period of time between anatomic discovery and realization that the endocrine function of the parathyroid gland was related to calcium homeostasis $^{4}$. However, basic features like volume of functioning glands and stroma and their functional correlation are still in controversy. Moreover, it has been observed by reviewing the literature and the texts that several works have been done on functional 
anatomy of the parathyroids in foreign countries but proper attention has not been given in our country ${ }^{6,7}$. Hence, the present histological study of the parenchyma (glandular portion) and stroma (fibrous part with blood vessels and fat) of human parathyroid gland has been designed to see whether there is any variation with age in Bangladeshi people as well as with those of the western studies.

\section{Methods}

The present study was performed in the Department of Anatomy, Dhaka Medical College, Dhaka, from January to December 2008 , on post mortem parathyroid glands of 60 Bangladeshi people in different age groups ranging from 15 to 75 years. Total 207 parathyroid glands were taken from those 60 cadavers. The human parathyroid glands were collected from unclaimed dead bodies that were under examination in the Department of Forensic Medicine of Dhaka Medical College, Dhaka. The samples were collected within 24 hours of death without any sign of putrefaction. All the samples were collected from medicolegal cases. During collection appropriate age, sex, and cause of death were noted from morgue's record book. The samples were brought to the Department of Anatomy, Dhaka Medical College, Dhaka. The samples were tagged immediately, which was bearing a code number for subsequent identification. Soon after collection, each sample was gently washed in tap water on a dissection tray. Blood and blood clots were removed as far as possible. Then the samples were fixed in $10 \%$ formol saline solution.

\section{Grouping of the Sample}

For convenience of description in relation to age, the collected samples were divided into three groups, according to Panijan et al ${ }^{8}$ (Table-I).

\section{Preparation of the histology slide}

Parathyroid glands were fixed in $10 \%$ formol saline in a plastic container. The tissues were washed in running tap water, dehydration was done with ascending grades of alcohol, cleared with xylene, infiltrated and embedded in paraffin. Paraffin blocks were cut $a^{5} \mathrm{~m}$ thickness and were stained with routine Harris' haematoxylin and eosin (H \& E) stain.

Estimation of percentage volume proportions of parenchyma and stroma:

20 best prepared slides were taken from each age group. The percentage volume proportions of parenchyma and stroma of parathyroid gland was determined with the point counting technique described by Aherne and Dunnill9. Point counting Zeiss I integrating eyepiece was prepared in a transparent plastic sheet and was placed into the eyepiece. This eyepiece contains a point network of 25 points spaced at $70 \mathrm{~m}$, arranged within a circle which delimits the counting field. The light compound microscope which was used for the microscopic measurement was OLYMPUS CHB, made in Tokyo, Japan. The point counting was done at low magnification ( 10 objective 10 eyepiece). The position of each point falling on any structural component was recorded for each field. Then the eyepiece was rotated 90 keeping the field constant. Again the position of the each point was recorded. Thus 50 points were recorded for each field. Five such fields or 250 points were studied on each section. The total number of points fitting each component was summed up and expressed as a percentage of the total number of points fitting the structural component of parathyroid glands. This percentage represents the percentage volume proportions of parenchyma and stroma.

\section{Statistical processing of data}

The data collected were processed and statistical analyses were done by using SPSS version 11.0. Comparison between superior and inferior parathyroid glands of right and left side was done by unpaired Student's ' $t$ ' test, and comparison between different age group was done by One way ANOVA (PostHoc).

\section{Ethical Clearance}

This research work was approved by the Ethical Review Committee of Dhaka Medical College, Dhaka. 


\section{Results}

\section{Right parathyroid glands}

Superior parathyroid glands: In the present study, the mean SD percentage volume of parenchyma was 65.502 .27 in group A (10-30 years), 56.40 12.57 in group B (31-60 years) and 41.252 .99 in group C (61-90 years) (Fig.1). In contrast, the mean SD percentage volume of stroma was 33.50 2.27 in group A, 40.30 3.83 in group B and 58.752 .99 in group C (Fig.2). The mean difference of both parenchyma and stroma in superior parathyroid glands among three groups was statistically significant $(\mathrm{p}<0.001)$.

Inferior parathyroid glands: In the present study, the mean SD percentage volume of parenchyma was 65.902 .33 in group A, 58.44 4.16 in group $\mathrm{B}$ and 40.000 .00 in group C (Fig.1). In contrast, the mean SD percentage volume of stroma was $34.102 .33,41.564 .16$ and 58.000 .00 in group $\mathrm{A}, \mathrm{B}$ and $\mathrm{C}$ respectively (Fig. 2). The mean difference of both parenchyma and stroma in inferior parathyroid glands among three groups was statistically significant $(\mathrm{p}<0.001)$.

However, the mean difference of parenchyma or stroma in between superior and inferior parathyroid glands of right side among group A, B and $\mathrm{C}$ was not statistically significant $(\mathrm{p}>0.50)$.

Table-I: Grouping of the sample in relation to age

\begin{tabular}{ccccc}
\hline Group & \multicolumn{2}{c}{ Age limit in years Number of person Number of collected } \\
parathyroid glands
\end{tabular}

Fig.1: Percentage volume of parenchyma of superior and inferior parathyroid glands of right and left side in different age groups.

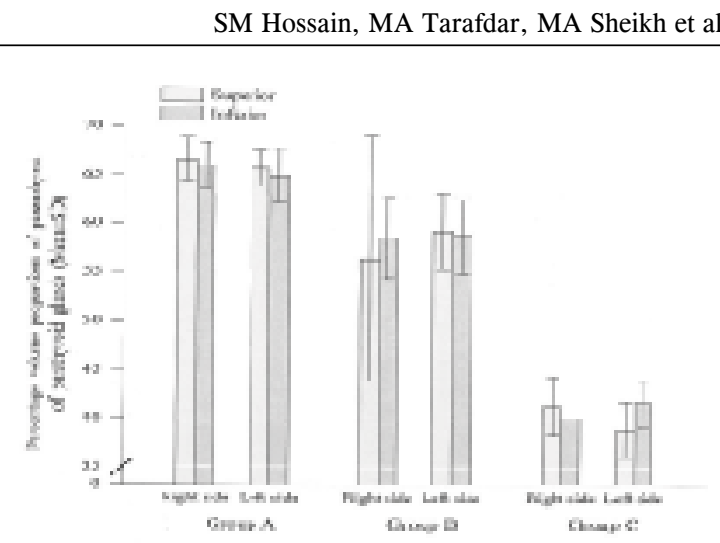

Fig. 2: Percentage volume of stroma of superior and inferior parathyroid glands of right and left side in different age groups.

\section{Discussion}

According to Rosai ${ }^{10}$ the average percentage of stroma in the adult parathyroid is about $40 \%$. According to Gartner and Hiatt ${ }^{2}$, the connective tissue stroma in older adults may occupy up to $60 \%$ of the gland. Ross and Pawlina ${ }^{3}$ stated that the connective tissue is more evident in the adult, with the development of fat cells that increase with age and ultimately constitute as much as $60-70 \%$ of the glandular mass. Bevelander and Ramaley ${ }^{11}$ stated that the connective tissue stroma in older adults may occupy up to $50-80 \%$ of the gland volume. MacSween and Whaley ${ }^{12}$ stated that stroma constitutes up to $30 \%$ of the normal adult gland. The findings of the present study have got similarity with the findings of the Gartner and Hiatt $^{2}$, Ross and Pawlina ${ }^{3}$, Rosai ${ }^{10}$, Bevelander and Ramaley ${ }^{11}$. However, the amount stated by MacSween and Whaley ${ }^{12}$ is lower than that of the present study. The difference in value may attribute racial variation or difference in sample preparation and histological technique.

\section{Conclusion}

In the present study, the percentage volume of connective tissue stroma was found to increase with increasing age with simultaneous decrease in glandular parenchyma. Further studies with lager samples and highly sophisticated technical backup, e.g. computerized stereotechnique, are recommended. 


\section{Acknowledgement}

We would like to acknowledge the authority of the Health, Nutrition \& Population Sector Programme (HNPSP) of Directorate General Health Services (DGHS) of the Government of the People's Republic of Bangladesh, and Dhaka Medical College, Dhaka for providing us with the grant for research.

\section{References}

1. Berkovitz BKB. Head and neck. In: Standring S, Ellis H, Healy JC, et al. eds. Gray's anatomy: the anatomical basis of clinical practice. 39th ed. London: Elsevier Churchill Livingstone; 2005. p.564-5.

2. Gartner LP, Hiatt JL. Color textbook of histology 3rd ed. Philadelphia: W.B. Saunders; 2006. p.314-6.

3. Ross MH, Pawlina W. Histology: a text and atlas with correlated cell and molecular biology. 5th ed. Baltimore: Lippincott Williams \& Wilkins; 2006. p.704-6.

4. Paloyan E, Lawrence AM, Straus FH. Hyperparathyroidism. New York: Grune \& Stratton; 1973.
5. MacCallum WG, Voegtlin C. On the relation of tetany to the parathyroid glands and to calcium metabolism. J Exp Med 1909; 11(1): 118-51.

6. Wang C. The anatomic basis of parathyroid surgery. J Ann Surg 1976; 183(3): 271-5.

7. Enayetullah M. Gross and histomorphological study of the thyroid and parathyroid glands in Bangladeshi people (MPhil Thesis). Dhaka: University of Dhaka; 1996.

8. Panijan RP, Grbesa D, Mederal P, et al. Do parathyroid glands from individuals of different age and gender contain lymph vessels? Coll Antropol 2006; 30(2): 369-73.

9. Aherne W, Dunnill MS. Quantitative aspects of placental structure. J Pathol Bacteriol 1966; 91: 123-39.

10. Rosai J. Rosai and Ackerman's surgical pathology. Vol.1. 9th ed. New Delhi: Elsevier Mosby; 2004. p.595-610.

11. Bevelander G, Ramaley JA. Essentials of histology. 7th ed. Saint Louis: C.V. Mosby; 1974. p.299-303.

12. MacSween RNM, Whaley K. Muir's textbook of pathology. 13th ed. London: Arnold; 1995. p.1103-5. 